\title{
Hydroxylamine interferes with the behavioral response to morphine dependence in mice*
}

\author{
STANISLAV REINIS \\ University of Waterloo, Waterloo, Ont., Canada
}

\begin{abstract}
Mice were injected daily by morphine sulfate for 22 days, then forced to drink morphine solution for 5 days, and finally injected with $0.5 \mathrm{M}$ hydroxylamine hydrochloride intracranially. Forth-eight hours after the injection, they were given the choice between morphine sulfate solution and water. Hydroxylamine-injected animals consumed less morphine solution than two control groups.
\end{abstract}

There is at present no substance available which is able to reverse easily and quickly the dependence on narcotic analgesics. Methadone administration is just a substitution therapy, exchange of one drug for a drug more socially acceptable. There have been already described cases of methadone addiction (Lennard et al, 1972). However, search for drugs treating the drug addiction is one of the mose important problems to be solved quickly by biomedical sciences.

The comparison of the mechanism of adaptation of bacteria to change of the substrate with the hypothetical models of drug tolerance led us to an assumption that antimetabolites reacting with the activated parts of the genome might interfere with some adaptive processes in the mammalian nervous system, too. In the experiments presented in this paper, we attempted to influence the drinking of morphine solution by morphine-dependent animals by intracranial injection of hydroxylamine $\left(\mathrm{NH}_{2} \mathrm{OH} . \mathrm{HCl}\right)$.

The method of the development of morphine dependence was essentially that of Nichols \& Hsiao (1967), as modified by Eriksson \& Kiianmaa (1971).

Ninety-three Swiss-Webster albino mice, males of average weight $37.9 \mathrm{~g}$ (SD 3.01) at the beginning of the experiment, were, after shipment from the supplier, left for 3 weeks in the vivarium of the department, where the in food and water consumption were measured daily. The mice were kept in cages in groups of five in order to avoid the changes in emotionality and brain biochemistry caused by isolation of individual animals.

Afterwards, they were offered the free choice between water and morphine sulfate solution $(0.5 \mathrm{mg} / \mathrm{ml})$ for 3 days. The fluids were in $100-\mathrm{ml}$ calibrated Kimax drinking vessels, and the consumption of both fluids was measured. After 3 days, the mice obtained water only for drinking and were injected daily with morphine sulfate, starting with the dose of $10 \mathrm{mg} / \mathrm{kg}$ of body weight, intraperitoneally. The

\footnotetext{
*This paper is sponsored by James Dyal, who takes full editorial responsibility for it. The work was supported by Grant MRC-DA-11 from DNHW-MRC Research Program on the Non-Medical Use of Drugs of Canada. I am thankful to M. Reinis for her excellent technical help.
}

morphine dosage was increased by $5 \mathrm{mg}$, until $30 \mathrm{mg} / \mathrm{kg}$ of body weight per day was being injected. This amount was kept constant up to the end of the injection series (22 days altogether).

For the following 5 days, the mice were not injected with morphine, but obtained only a solution of morphine sulfate $(0.5 \mathrm{mg} / \mathrm{ml})$ for drinking.

On the 27 th day of the experiment, the morphine solution was replaced again by drinking water, and the groups of animals were injected intracranially with 20 microliters of $0.5 \mathrm{M}$ sodium chloride solution or 20 microliters of $0.5 \mathrm{M}$ hydroxylamine hydrochloride neutralized with sodium hydroxide to $\mathrm{pH}$ 7.35. The injection needle was inserted through the temporal muscle parallel with the surface of the cerebral cortex. Thus, we tried to avoid damage to the brain tissue.

The period of abstinence lasted 2 days, during which water and food consumption, rectal temperature, and body weight were recorded.

After the period of abstinence, the mice were given the choice between the morphine solution and water again. Consumption of water, morphine solution, and food were measured and recorded for another 10 days.

Body weight and food consumption did not change substantially during the series of morphine injections. Body weight temporarily decreased after the intracranial injection of saline or hydroxylamine, but the food consumption reached the original values within $48 \mathrm{~h}$ after saline and 4 days after hydroxylamine injections. Comparison with the group of mice that were not injected at all shows that the decrease of body weight may have been caused partly by the intracranial injection, partly by the withdrawal of morphine.

Measuring of rectal temperature during the period of

Table 1

Development of Body Weight During and After Morphine Injections

\begin{tabular}{|c|c|c|c|c|c|c|}
\hline \multirow[b]{2}{*}{ Day } & \multicolumn{2}{|c|}{ Saline Group } & \multicolumn{2}{|c|}{$\begin{array}{l}\text { Hydroxylamine } \\
\text { Group }\end{array}$} & \multicolumn{2}{|c|}{ No Injection } \\
\hline & Average & $\mathrm{SD}$ & Average & $\mathrm{SD}$ & Average & $\mathrm{SD}$ \\
\hline 1 & 36.48 & 3.60 & 37.47 & 2.57 & 39.49 & 2.98 \\
\hline 22 & 37.87 & 1.27 & 38.18 & 1.10 & 38.53 & 2.85 \\
\hline 23 & 37.47 & 2.12 & 37.98 & 1.60 & 38.42 & 1.94 \\
\hline 24 & 37.33 & 1.69 & 37.66 & 2.21 & 38.62 & 2.09 \\
\hline 25 & 37.48 & 2.81 & 37.84 & 2.18 & 38.23 & 1.99 \\
\hline 26 & 37.40 & 3.30 & 37.81 & 2.09 & 38.14 & 3.14 \\
\hline 27 & 37.37 & 2.92 & 38.50 & 2.66 & 38.33 & 3.50 \\
\hline \multicolumn{7}{|c|}{$\begin{array}{l}\text { Injec- } \\
\text { tion }\end{array}$} \\
\hline 1 & 35.13 & 2.46 & 33.53 & 2.66 & 37.45 & 2.30 \\
\hline 2 & 35.28 & 2.82 & 33.31 & 2.90 & 38.34 & 2.53 \\
\hline 3 & 34.25 & 3.75 & 33.47 & 2.95 & 37.95 & 1.63 \\
\hline 4 & 34.00 & 2.49 & 34.44 & 3.09 & 38.21 & 2.11 \\
\hline
\end{tabular}


Table 2

Rectal Temperature of Mice After the Series of Morphine Injections

\begin{tabular}{|c|c|c|c|c|c|c|}
\hline \multirow[b]{2}{*}{ Day } & \multicolumn{2}{|c|}{ Saline } & \multicolumn{2}{|c|}{ Hydroxylamine } & \multicolumn{2}{|c|}{ No Injection } \\
\hline & Average & SD & Average & SD & Average & SD \\
\hline $\begin{array}{l}22 \\
23 \\
24 \\
25 \\
26 \\
27\end{array}$ & $\begin{array}{l}37.29 \\
38.26 \\
38.17 \\
37.96 \\
38.15 \\
38.31\end{array}$ & $\begin{array}{l}0.88 \\
0.61 \\
0.52 \\
0.81 \\
0.76 \\
0.95\end{array}$ & $\begin{array}{l}37.54 \\
38.04 \\
38.11 \\
37.90 \\
38.10 \\
38.31\end{array}$ & $\begin{array}{l}0.83 \\
0.92 \\
0.66 \\
0.79 \\
0.87 \\
0.78\end{array}$ & $\begin{array}{l}37.27 \\
38.26 \\
38.50 \\
37.83 \\
37.69 \\
38.24\end{array}$ & $\begin{array}{l}0.70 \\
0.58 \\
0.63 \\
0.83 \\
0.90 \\
0.99\end{array}$ \\
\hline \multicolumn{7}{|c|}{ Injection of Hydroxylamine or Saline } \\
\hline $\begin{array}{l}28 \\
29 \\
30 \\
31\end{array}$ & $\begin{array}{l}36.86 \\
37.94 \\
37.63 \\
37.90\end{array}$ & $\begin{array}{l}1.00 \\
2.18 \\
2.14 \\
2.46\end{array}$ & $\begin{array}{l}36.68 \\
37.44 \\
37.80 \\
38.20\end{array}$ & $\begin{array}{l}2.05 \\
2.22 \\
2.21 \\
2.68\end{array}$ & $\begin{array}{l}37.01 \\
38.68 \\
38.70 \\
38.44\end{array}$ & $\begin{array}{l}2.06 \\
2.23 \\
2.09 \\
1.99\end{array}$ \\
\hline
\end{tabular}

Table 3

Water and Morphine Consumption Before and After the Injection of Hydroxylamine (Values Expressed in Milliliters for Group of Five Animals)

Water Morphine

Water only last 3

before experiment

$41.4 \pm 3.7$

Choice between water and morphine before injections

$39.0 \pm 4.1 \quad 1.5 \pm 0.3 \quad 3.6 \% *$

Water consumption

during morphine

injections

Forced morphine drinking after morphine injec- 2 tions (individual days)

$40.4 \pm 3.2$

\begin{tabular}{ll}
1 & $33.6 \pm 3.2$ \\
2 & $52.6 \pm 4.9$ \\
3 & $71.4 \pm 10.1$ \\
4 & $79.9 \pm 6.6$ \\
5 & $52.6 \pm 5.2$ \\
6 & \\
\hline
\end{tabular}

*Morphine consumption as percent of total fluid consumption.

forced morphine drinking did not show any significant decrease or increase. After the morphine withdrawal and injection of hydroxylamine or saline, the rectal temperature temporarily decreased, but returned to normal within $48 \mathrm{~h}$ (Tables 1 and 2).

All data indicate that the daily injection of $30 \mathrm{mg}$ of morphine sulfate for 22 days produced some degree of morphine dependence. However, the withdrawal symptoms resembled the consequences of the intracranial injections and were hard to evaluate.

Nevertheless, the whole procedure, morphine injections and food morphine drinking, caused an increase in the drinking of morphine solution. In a free choice situation, the mice drank, on average, significantly more morphine solution after the series of morphine injections than they had before it (see Tables 3 and 4). At the beginning of the experiment, the mice consumed only, on average, $0.30 \mathrm{ml}$ morphine solution per animal and day (3.8\% of their total fluid consumption, $8.1 \mathrm{ml}$ ). After the series of morphine injections, the amount of morphine solution increased both in absolute values and in percentage of the total fluid consumption. Animals injected intracranially with hydroxylamine consumed substantially less morphine than did the saline-injected ones or those without any injection. The results were evaluated by chi-square test. The differences between hydroxylamine-injected animals and their own consumption before the forced morphine drinking are not significant, whereas animals injected with saline or not injected at all drank significantly more morphine solution, p usually being .01 .

Hydroxylamine did not block the behavioral expression of drug dependence completely. The hydroxylamine-treated mice consumed about twice as much morphine as the nonaddicted mice.

Our experiments indicate that intracranial injection of hydroxylamine interferes with the behavioral response of the animals to morphine. We are still unable to explain the biochemical mechanisms of this effect. A hypothesis was formulated earlier, attributing the effect of a potent antimetabolite hydroxylamine to its action on activated DNA (Reinis, 1970). Development of the drug tolerance and dependence is probably one of the metabolic adaptation phenomena associated with the activation of new parts of the genome. Hydroxylamine

Table 4

Water and Morphine Consumption After the Injection of Hydroxylamine

\begin{tabular}{|c|c|c|c|c|c|c|c|c|c|}
\hline \multirow{2}{*}{$\begin{array}{c}\text { Day of } \\
\text { Experiment }\end{array}$} & \multicolumn{3}{|c|}{ Hydroxylamine } & \multicolumn{3}{|c|}{ Saline } & \multicolumn{3}{|c|}{ No Injection } \\
\hline & Water & Morphine & Percent & Water & Morphine & Percent & Water & Morphine & Percent \\
\hline & \multicolumn{9}{|c|}{ Forced Water Drinking } \\
\hline \multirow[t]{2}{*}{$\begin{array}{l}27 \\
28\end{array}$} & $\begin{array}{l}21.8 \pm 3.4 \\
47.0 \pm 4.2\end{array}$ & & & $\begin{array}{l}34.2 \pm 6.1 \\
55.2 \pm 9.2\end{array}$ & & & $\begin{array}{l}34.8 \pm 6.2 \\
59.0 \pm 9.4\end{array}$ & & \\
\hline & & & & Choice of & Morphine o & Water & & & \\
\hline $\begin{array}{l}29 \\
30 \\
31 \\
32 \\
33 \\
34 \\
35 \\
36\end{array}$ & $\begin{array}{l}24.7 \pm 4.1 \\
34.5 \pm 5.6 \\
47.0 \pm 5.8 \\
48.6 \pm 7.8 \\
52.8 \pm 6.9 \\
34.2 \pm 5.1 \\
45.0 \pm 6.0 \\
43.4 \pm 7.2\end{array}$ & $\begin{array}{l}3.6 \pm 0.8 \\
3.4 \pm 0.7 \\
3.4 \pm 0.6 \\
4.7 \pm 0.8 \\
2.8 \pm 0.6 \\
3.4 \pm 0.5 \\
4.2 \pm 0.9 \\
3.8 \pm 0.8\end{array}$ & $\begin{array}{r}12.7 \\
8.9 \\
6.7 \\
8.8 \\
5.0 \\
9.0 \\
8.5 \\
8.1\end{array}$ & $\begin{array}{l}30.0 \pm 4.8 \\
42.5 \pm 6.2 \\
48.2 \pm 6.5 \\
45.0 \pm 6.9 \\
53.8 \pm 9.3 \\
39.1 \pm 8.1 \\
50.8 \pm 9.2 \\
57.5 \pm 9.7\end{array}$ & $\begin{aligned} 8.2 & \pm 2.1 \\
5.7 & \pm 6.2 \\
10.3 & \pm 2.2 \\
10.6 & \pm 1.9 \\
8.2 & \pm 2.0 \\
7.5 & \pm 2.0 \\
12.5 & \pm 1.6 \\
5.4 & \pm 1.8\end{aligned}$ & $\begin{array}{r}21.5 \\
11.8 \\
17.6 \\
19.1 \\
13.2 \\
16.1 \\
19.7 \\
8.6\end{array}$ & $\begin{array}{l}36.0 \pm 7.1 \\
34.8 \pm 6.2 \\
38.3 \pm 5.5 \\
40.0 \pm 6.1 \\
40.8 \pm 6.6 \\
35.7 \pm 7.1 \\
30.8 \pm 4.8 \\
44.0 \pm 4.9\end{array}$ & $\begin{array}{l}6.8 \pm 0.8 \\
7.8 \pm 1.3 \\
6.0 \pm 0.8 \\
8.3 \pm 1.2 \\
8.8 \pm 1.4 \\
4.7 \pm 2.0 \\
6.0 \pm 0.3 \\
5.4 \pm 0.5\end{array}$ & $\begin{array}{l}14.9 \\
18.3 \\
13.5 \\
17.2 \\
17.7 \\
11.6 \\
16.3 \\
10.9 \\
\end{array}$ \\
\hline
\end{tabular}


may react with this active DNA, change its transcription and translation and thus interfere with the metabolic adaptation.

Our experiments are comparable with those of Cohen et al (1965), Yamamoto et al (1967), Smith et al (1966), Way et al (1968), Feinberg \& Cochin (1969), and Loh et al (1969), which demonstrated that the development of morphine tolerance and dependence may be blocked by actinomycin $\mathrm{D}$, puromycin, cycloheximide, etc. The main difference between their observations and ours is that we blocked the developed existing dependence ex post. Other substances with similar effect, but without several toxic effects of hyrodxylamine, may be found which may be useful tools in the treatment of drug dependence and tolerance.

\section{REFERENCES}

Cohen, M., Keats, A. S., Krivoy, W., \& Ungar, G. Effect of actinomycin-D on morphine tolerance. Proceedings of the Society of Experimental Biology \& Medicine, 1965, 119, 381-384.

Eriksson, K., \& Kiianmaa, K. Genetic analysis of susceptibility to morphine addiction in inbred mice. Annals of Medical
Experimental Biology Fen., 1971, 49, 73-78.

Feinberg, M. P., \& Cochin, J. Effect of weekly doses of cycloheximide on tolerance to morphine in the rat. Pharmacologist, 1969, 11, 256.

Lennard, H. L., Epstein, L. J., \& Rosenthal, M. S. The methadone illusion. Science, 1972, 176, 881-884.

Loh, H. H., Shen, F. N., \& Way, E. L. Effect of cycloheximide on the development of morphine tolerance and physical dependence. Pharmacologist, 1969, 11, 188.

Nichols, J. R., \& Hsiao, S. Addiction liability of albino rats: Breeding for quantitative differences in morphine drinking. Science, 1967, 157, 561-563.

Reinis, S. Delayed learning deficit produced by hydroxylamine. Physiology \& Behavior, 1970, 5, 253-256.

Smith, A. A., Karmin, M., \& Gavitt, J. A. Blocking effect of puromycin, ethanol, and chloroform on the development of tolerance to an opiate. Biochemical Pharmacology, 1966, 15, 1877-1879

Way, E. L., Loh, H. H., \& Shen, F. H. Morphine tolerance physical dependence and synthesis of brain 5-hydroxy tryptamine. Science, $1968,162,1290-1292$.

Yamamoto, I., Inoki, R., Tawari, Y., \& Iwatsubo, K. Inhibitory effect of 8-azaguanine on the development of tolerance in the analgesic action of morphine. Japanese Journal of Pharmacology, 1967, 17, 140-142.

(Received for publication August 28, 1973.)

\section{The consumption of saccharin and glucose solutions by mongolian gerbils*}

\section{STEPHEN C. PIERSON, ROBERT W. SCHAEFFER and GLEN D. KING $\dagger$ \\ Florida State Universitv, Tallahassee, Fla. 32306}

*Supported in part by Public Health Research Grants MG-08775 and MH-12025 from the National Institute of Mental Health, R. W. Schaeffer, principal investigator.

TS. C. Pierson is now with the Cedar Creek Natural History Area, Department of Ecology and Behavioral Biology, University of Minnesota; R. W. Schaeffer and G. D. King are now at Auburn University, Auburn, Ala. 36830 . Reprints may be obtained from R. W. Schaeffer. Appreciation is extended to Jeff Luby for competent and reliable assistance in the collection of this data.
Mongolian gerbils exhibited a preference for $3 \%$ glucose over water, a $.125 \%$ saccharin solution, and a combined $3 \%$ glucose and $.125 \%$ saccharin solution that has been found to elicit excessive fluid consumption in rats. Glucose solution intakes in excess of twice the gerbil's normal water intakes were found. Consumption of the combined glucose and saccharin solution, however, did not exceed water intake consumption.

Polydipsia resulting from the synergistic action of saccharin and glucose $(S+G)$ has been demonstrated to 